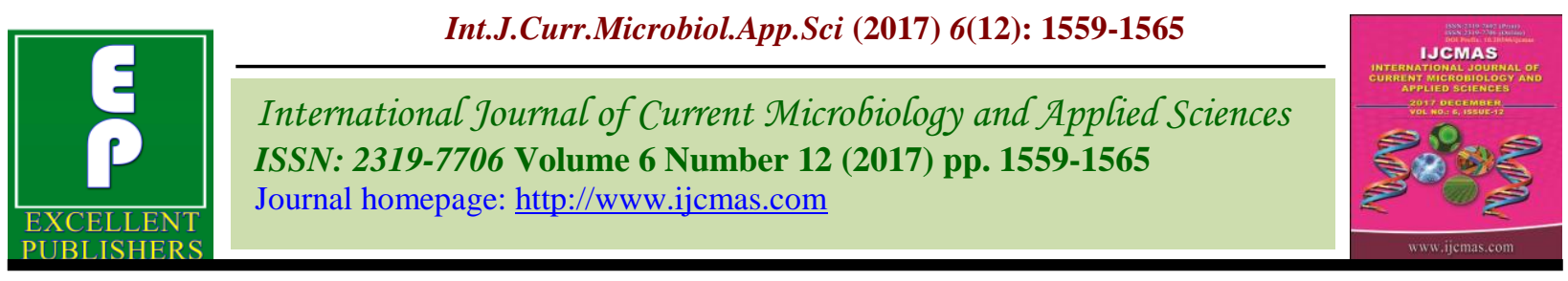

Original Research Article

https://doi.org/10.20546/ijcmas.2017.612.175

\title{
Sources of Agricultural Information Accessed by Farmers in Haryana, India
}

\author{
Anju Duhan* and Satbir Singh \\ Research Scholar, HSB, GJUS\&T Hisar-125001, Haryana, India \\ *Corresponding author
}

\section{A B S T R A C T}

\begin{tabular}{|l|}
\hline K e y w o r d s \\
Information, \\
Sources, Weather \\
Forecasting, \\
Agriculture \\
Activities.
\end{tabular}

Keywords

Information,

Sources, Weather

Forecasting,

Agriculture

Activities.

\section{Introduction}

To interact with the other factors of production, agricultural information is an essential factor. To control over their resources and decision-making processes information empowers farmers. The farmers are facilitated in decision-making towards improved agricultural production, processing, trading and marketing through an effective and efficient release system of essential information and technology services (Maningas et al., 2005). Research, education and agricultural organizations can help farmers by supplying adequate information in better decision making. So, to manage and to improve the functioning of a particular agricultural information system, there is a need to understand it initially (Demiryurek et al., 2008). Weather and natural variables affect agriculture sector and its productivity due to which, it is considered as unique sector. An institution or individual that creates or brings about a message is considered as an information source. Relevance, timelessness, accuracy, cost effectiveness, reliability, usability, exhaustiveness and aggregation level are the main characteristics of a good information source.

To be certain that decisions made on the farm will give effective outcome, it is important to recognize and evaluate the risks in agriculture. Considering the fact that agricultural products are related to natural processes, so the farmers are more likely to 
face risks than other businesses. The natural events such as poor weather conditions have a negative impact on the production in farming. There may also a further increase in the economic costs due to the major climatic disasters. Therefore, the farmers have to develop the strategies with the assistance of government to cope with these adverse natural events (Girdziutea, 2012). The essential features in agriculture are uncertainty and risk. The sources of uncertainty and risk in agriculture are the events related to climate and weather conditions, changes in prices in agriculture produce and inputs such as fertilizer and pesticides, farm machinery etc. and risks related to financial policy and regulatory risks. All the risks involved in agriculture are linked rather than their independency (Aimin, 2010). Farm production is affected by several kinds of risks. Farmers' production decisions and wellbeing are directly affected by these risks. Due to weather conditions, plant diseases and price instability farmers have to face many challenges in their economic activity. Weather, market developments and other events are beyond the control of farmers but have a direct effect on the returns from agricultural activities (Aidoo et al., 2014). Therefore, this study was undertaken with the objective to trace out the source of information used by the farmers for performing agricultural activities in Haryana.

To utilize information and knowledge to improve productivity especially in agriculture, advancements in the information and communication technologies provide an opportunity for developing and agrarian countries like India (Lwoga, 2010). Due to differing literacy, technical skills and functional digital content, the farmers who are poor from available resources are mainly affected in their ability to use information and communication technologies unfortunately (Ghatak, 2007). There is a positive relationship between the increased flow of knowledge and information and agricultural development (Fawole, 2008). The large amount of knowledge and the relevant information exists in research institutions, universities and public offices of the country but, only a small amount of this agricultural information is accessible to rural farmers. This status largely depicts the weak linkages between research, extension and farmers. Thus the poor linkage between these institutions and farmer is the main reason farmers could not use new technologies to improve their farming activities in the developing countries (Lwoga et al., 2011).

\section{Materials and Methods}

The present study is mainly based on primary data and exploratory in nature. The data has been collected with the help of a wellstructured questionnaire from the respondents through an interview schedule. The questionnaire is administered on 567 randomly selected farmers from all over the Haryana. The collected data has been analyzed by using the statistical tool percentage analysis.

\section{Results and Discussion}

The sampled data is analyzed to investigate the sources of information used by the farmers for weather forecasting and performing agricultural activities accordingly. The existing literature pointed out the number of information sources available to the farmers but they approach them according to their age, understanding level etc. The proportions of responses sharing the agreement with a particular source of information used are computed for all data set and also for different age groups and educational qualification groups with the reference of information sources used presented in Table 1, 2, 3, 4 and 5. 
The farming activities involves number of decisions which required varied information such as weather conditions, market prices, seeds, fertilizers, pesticides, and farm equipments etc. The Table 1 depicts the various sources of latest information about farming activities applied by the respondents. Newspaper is the most popular source of getting latest information about the agricultural activities. $40.2 \%$ respondents used newspaper as a major source of information followed by state agriculture department (39.7\%), television (38.4\%), agricultural universities $(33.5 \%)$ and radio (23.8 \%). In state agriculture department, agriculture development officer, horticulture development officer and other agriculture officers from different agriculture offices provided different kinds of information to the farmers from time to time. Agricultural input dealers were regularly in touch with the farmers. They also gave timely information to the farmers related to new varieties of seeds, pesticides, etc. $21.9 \%$ farmers got latest information from the input dealers followed by private companies $(17.1 \%)$ and fellow farmers $(16.2 \%)$. A very little percentage of farmers $(8.8 \%)$ got latest information from the use of internet. It shows that farmers were yet away from the technology which was moving fast in this era. Literacy level of the respondents may be the reason behind this.

To investigate how the information sources are spread among farmers on the basis of education, cross table is prepared from the sample data which is presented in the Table 2. The table explains the association between the education and the choice of sources of latest information uses by the respondent for performing agricultural activities. There were different sources of information available to the respondents, but they used them according to their educational level. For example, low educated farmers could not use internet so much for getting information. Other than internet, there were agricultural universities, state government department, radio, television, newspaper, etc available as a source of latest information. In spite of these, farmers may access agriculture input dealers and representatives of the private companies, but theses sources were not so reliable sources of information some times. The table also represents the column-wise data. Out of the total below matric farmers, maximum got latest information about agricultural activities from newspaper (16.9\%) followed by television (16.2\%) and radio (13.4\%). The reason may be the easily accessibility of these sources in the rural areas. $11.3 \%$ below matric respondents depended on fellow farmers for latest information. Private companies selling different agricultural inputs in the villages and nearby areas also provided information to the farmers about agricultural activities which were not the authentic source of information. Generally low educated farmers approached these. But the maximum graduate (27.1\%) and post graduate farmers (23.9\%) approached the agricultural universities for latest agricultural information followed by the state agriculture department and newspaper. These respondents also used internet as a source of latest information. Because these institutions provided modern and scientific and also timely information to the farmers. Farmers having higher education have more tendencies to consult agricultural universities and state agriculture department to get information on agricultural activities. It is obvious that educated farmers can better interact with scientists and experts in the universities. Television and newspaper were found most popular source of information accessed by all the categories of farmers with respect to education. 
Table.1 Sources of latest information about agricultural activities

\begin{tabular}{|c|l|c|}
\hline Sr. No. & \multicolumn{1}{|c|}{ Sources } & Percentage \\
\hline 1. & Newspaper & 40.2 \\
\hline 2. & State agriculture department & 39.7 \\
\hline 3. & Television & 38.4 \\
\hline 4. & Agricultural universities & 33.5 \\
\hline 5. & Radio & 23.8 \\
\hline 6. & Agriculture input dealers & 21.9 \\
\hline 7. & Private companies & 17.1 \\
\hline 8. & Fellow farmers & 16.2 \\
\hline 9. & Internet & 08.8 \\
\hline
\end{tabular}

Table.2 Education and sources of latest information about agricultural activities

\begin{tabular}{|l|c|c|c|c|c|}
\hline \multirow{2}{*}{ Sources } & \multicolumn{5}{c|}{ Education } \\
\cline { 2 - 6 } & $\begin{array}{c}\text { Below } \\
\text { matric }\end{array}$ & Matric & $\begin{array}{c}\text { Senior } \\
\text { Secondary }\end{array}$ & Graduate & $\begin{array}{c}\text { Post } \\
\text { Graduate }\end{array}$ \\
\hline Agricultural universities & $24(7.5)$ & $64(14.6)$ & $35(14.4)$ & $46(27.1)$ & $17(23.9)$ \\
\hline State agriculture department & $41(12.8)$ & $67(15.3)$ & $50(20.6)$ & $36(21.1)$ & $17(23.9)$ \\
\hline Private companies & $32(10.0)$ & $30(6.8)$ & $16(6.6)$ & $5(2.9)$ & $0(0.0)$ \\
\hline Agriculture input dealers & $33(10.3)$ & $41(9.4)$ & $22(9.1)$ & $3(1.8)$ & $1(1.4)$ \\
\hline Radio & $43(13.4)$ & $54(12.3)$ & $16(6.6)$ & $5(2.9)$ & $1(1.4)$ \\
\hline Television & $52(16.2)$ & $82(18.7)$ & $39(16.0)$ & $21(12.4)$ & $9(12.7)$ \\
\hline Newspaper & $54(16.9)$ & $76(17.4)$ & $44(18.1)$ & $29(17.1)$ & $15(21.1)$ \\
\hline Internet & $5(1.6)$ & $3(0.7)$ & $8(3.3)$ & $23(13.5)$ & $11(15.6)$ \\
\hline Fellow farmers & $36(11.3)$ & $21(4.8)$ & $13(5.3)$ & $2(1.2)$ & $0(0.0)$ \\
\hline
\end{tabular}

Table.3 Age and sources of latest information about agricultural activities

\begin{tabular}{|l|c|c|c|c|c|}
\hline \multirow{2}{*}{ Sources } & \multicolumn{5}{|c|}{ Age } \\
\cline { 2 - 6 } & $\mathbf{1 8 - 2 5}$ & $\mathbf{2 5 - 3 5}$ & $\mathbf{3 5 - 4 5}$ & $\mathbf{4 5 - 5 5}$ & $\begin{array}{c}\mathbf{5 5} \text { and } \\
\text { above }\end{array}$ \\
\hline Agricultural universities & $13(13.3)$ & $67(19.2)$ & $48(13.2)$ & $48(13.7)$ & $14(7.1)$ \\
\hline $\begin{array}{l}\text { State agriculture } \\
\text { department }\end{array}$ & $11(11.2)$ & $72(20.6)$ & $63(17.3)$ & $58(16.6)$ & $21(10.7)$ \\
\hline Private companies & $6(6.1)$ & $13(3.7)$ & $31(8.5)$ & $27(7.7)$ & $20(10.2)$ \\
\hline Agriculture input dealers & $5(5.1)$ & $21(6.0)$ & $35(9.6)$ & $36(10.3)$ & $27(13.7)$ \\
\hline Radio & $10(10.2)$ & $19(5.4)$ & $37(10.1)$ & $40(11.4)$ & $29(14.7)$ \\
\hline Television & $19(19.4)$ & $53(15.2)$ & $62(17.0)$ & $54(15.4)$ & $30(15.2)$ \\
\hline Newspaper & $21(21.4)$ & $62(17.8)$ & $63(17.3)$ & $54(15.4)$ & $28(14.2)$ \\
\hline Internet & $9(9.2)$ & $27(7.7)$ & $7(1.9)$ & $5(1.4)$ & $2(1.0)$ \\
\hline Fellow farmers & $4(4.1)$ & $15(4.3)$ & $19(5.2)$ & $28(8.0)$ & $26(13.2)$ \\
\hline
\end{tabular}


Table.4 Sources of latest information regarding weather forecasting

\begin{tabular}{|c|c|c|}
\hline Sr. No. & Sources & Percentage \\
\hline 1. & Newspaper & 55.9 \\
\hline 2. & Television & 39.3 \\
\hline 3. & Radio & 35.1 \\
\hline 4. & SMS on your mobile & 31.0 \\
\hline 5. & Fellow farmers & 13.1 \\
\hline 6. & Internet & 11.5 \\
\hline
\end{tabular}

Table.5 Education and sources of latest information about weather forecasting

\begin{tabular}{|l|c|c|c|c|c|}
\hline \multirow{2}{*}{ Sources } & \multicolumn{5}{c|}{ Education } \\
\cline { 2 - 6 } & $\begin{array}{c}\text { Below } \\
\text { matric }\end{array}$ & Matric & $\begin{array}{c}\text { Senior } \\
\text { Secondary }\end{array}$ & Graduate & $\begin{array}{c}\text { Post } \\
\text { Graduate }\end{array}$ \\
\hline Newspaper & $84(31.6)$ & $122(33.9)$ & $61(34.5)$ & $27(24.5)$ & $11(22.9)$ \\
\hline Radio & $62(23.4)$ & $76(21.1)$ & $19(10.7)$ & $9(8.2)$ & $5(10.4)$ \\
\hline Television & $56(21.2)$ & $85(23.7)$ & $37(20.9)$ & $16(14.5)$ & $7(14.6)$ \\
\hline SMS service on mobile & $30(11.3)$ & $52(14.4)$ & $41(23.2)$ & $35(31.9)$ & $14(29.1)$ \\
\hline Internet & $6(2.3)$ & $12(3.3)$ & $16(9.0)$ & $21(19.1)$ & $9(18.8)$ \\
\hline Fellow farmers & $29(10.2)$ & $13(3.6)$ & $3(1.7)$ & $2(1.8)$ & $2(4.2)$ \\
\hline
\end{tabular}

Age, which is one of the indicators of experience, wisdom and to try new things, was investigated for association with the sources of information about agriculture. Their association is measured through proportions and counts tabulated in the table 3. The farmers used different sources of information to increase their awareness about crop insurance according to their maturity level. The major sources were radio, television, banks and financial institutions in their areas, internet facilities, etc. State agriculture department which were the very authentic sources of information about the agricultural activities, were highly accessed by the farmers under the age group of 25-35, followed by 35-45 and 45-55. Under the age group of $18-25$, the maximum number of farmers $(21.4 \%)$ used newspaper as a source of information followed by television $(19.4 \%)$ and agricultural universities (13.3\%). In the age group of 25-35, state agriculture department was highly approached $(20.6 \%)$ source of information for agricultural activities followed by agricultural universities (19.2\%), newspaper (17.8\%) and television (15.2\%). Internet was highly accessed by the age group of $18-25(9.2 \%)$ and only $1.0 \%$ farmers under the age group of 55 and above used internet. The age group of 55 and above (13.2\%) used fellow farmers for getting latest information of agricultural activities followed by $45-55(8.0 \%), 35-45(5.2 \%)$ and $25-35$ $(4.3 \%)$. The mature respondents (55 and above) used agricultural input dealers for getting agricultural information in highest percentage $(13.7 \%)$ followed by $45-55$ (10.3\%), 35-45 (9.6\%) and 25-35 (6.0\%).

Table 4 states the sources of latest information regarding the weather used by the sampled population. Information about weather forecasting is very helpful for farmers to carry forward the adequate farming activities on right time and in a right way. Thus, it means a lot for the farmers as it is frequently used by farmers for their operational activities. The data stated that 
maximum number of farmers got latest weather information from newspaper $(55.9 \%)$ followed by television $(39.3 \%)$, radio $(35.1 \%)$ and SMS services on the mobile (31.0\%). Newspaper, the print media, was the most reliable and authentic source of information considered by the farmers. Only $11.5 \%$ farmers used internet as a source of latest information about weather. In these days SMS services on the mobile of the farmers are also encouraged by the state agricultural universities. Farmers also depended on the fellow farmers (13.1\%) for the information about weather.

The table provides the figures that how education affects the farmers' choices of getting information about weather forecasting. The sources of information were newspaper, radio, television, internet, fellow farmers and SMS services provided by agricultural universities on the mobiles of the farmers, etc. The farmers used these sources according to their reach and educational level. For example, low educated farmers were not comfortable in using internet or SMS services. Thus, the data showed that the maximum below matric $(31.6 \%)$, matric $(33.9 \%)$ and senior secondary (34.5\%) farmers used newspaper as a source of latest information about weather for performing farming activities accordingly followed by radio $(23.4 \%)$ and television $(21.2 \%)$ in case of below matric, television $(23.7 \%)$ and radio $(21.1 \%)$ in case of matric farmers. $23.2 \%$ senior secondary farmers used SMS service on their mobile phone for latest information followed by newspaper (34.5\%). The maximum percentage of highly educated farmers (post graduate) used information through SMS services for their farming activities followed by the newspaper. Thus, it was concluded that as educational level of farmers' increased, they used reliable and government authorized sources of information. So, education means a lot towards using the sources of authentic information about farming activities. The farming activities involves number of decisions which required varied information such as weather conditions, market prices, seeds, fertilizers, pesticides, farm equipments, etc. There are various sources of latest information available about farming activities applied by the respondents. The farmers use sources of information according to their education level. A very little percentage of farmers got latest information from the use of internet. It shows that farmers were yet away from the technology which is moving fast in this era. Literacy level of the respondents may be the reason behind this. Low educated farmers generally approach agriculture inputs dealers which are not considered as an authentic source of information. Newspaper was the most popular source of getting latest information about the agricultural activities followed by television and agricultural universities. State agriculture departments which are the standardized source of information about the agricultural activities, were highly accessed by the farmers under the age group of 25-35, followed by 35-45 and 45-55. A very little number of farmers under the age group of 55 and above used internet. In current days SMS services on the mobile of the farmers are also encouraged by the state agricultural universities. Thus, it is concluded that as education level of farmers' increases, they use reliable and government authorized sources of information. So, education means a lot towards using the sources of authentic information about farming activities.

\section{Acknowledgment}

The authors are thankful to Dr. Ved Pal sheera, Professor, Haryana School of Business, Guru Jambheshwar University of Science and Technology, Hisar for providing valuable guidance and suggestions during the study. 


\section{References}

Aidoo, R., Mensah, J.O., Wie, O. and Awunyo-vitor, D. (2014). Prospects of crop insurance as a risk management tool among arable crop farmers in Ghana. Asian Economic and Financial Review. 4(3): 341-354.

Aimin, H. (2010). Uncertainty, risk aversion and risk management in agriculture. Agriculture and Agricultural Science Procedia. 1: 152-156.

Demiryurek, K., Erdem, H., Ceyhan,V., Atasever, S. and Uysal, O. (2008). Agricultural information system and communication networks: The case of dairy cattle farmers in Samsun Province of Turkey. Information Research. 13:343.

Fawole, O.P. (2008). Pineapple farmers' information sources and usage in Nigeria. Bulgarian Journal of Agricultural Science. 14 (4): 381-389.

Ghatak, S. (2007). Brief note on ICTs. Retrieved from: http://topics. developmentgateway.org/poverty/rc/fil edownload.do $\sim$ itemId=1098665
Girdziutea, L. (2012). Risks in agriculture and opportunities of their integrated evaluation. Procedia - Social and Behavioral Sciences. 62: 783-790.

Lwoga, E.T. (2010). Bridging the knowledge and information divide: the case of selected telecenters and rural radio in Tanzania. The Electronic Journal on Information Systems in Developing Countries. 43(6): 1-14.

Lwoga, E.T., Stilwell, C. and Ngylube, P. (2011). Access and use of agricultural information and knowledge in Tanzania. Library Review. 60 (5): 383395

Maningas, R. V., Perez, V. O., Macaraig, A. J., Alesna, W. T. and Villagonzalo, J. (2005). Electronic information dissemination through the farmers' Information and Technology Services (FITS)/Techno Pinoy Program. Bringing information and technology within the reach of the farmers. Retrieved from http://jsai.or.jp/afita/ afita-conf/2000/part08/p231.pdf, 2000.

\section{How to cite this article:}

Anju Duhan and Satbir Singh. 2017. Sources of Agricultural Information Accessed by Farmers in Haryana, India. Int.J.Curr.Microbiol.App.Sci. 6(12): 1559-1565.

doi: https://doi.org/10.20546/ijcmas.2017.612.175 